Article

\title{
Investigation of the Performance of a Heat Pump Using Waste Water as a Heat Source
}

\section{Ali Kahraman ${ }^{1, *}$ and Alaeddin Çelebi ${ }^{2}$}

1 Technical Education Faculty, Mechanical Education Department, Selçuk University, 42003, Konya, Turkey

2 Technical Science Vocational High School, Selçuk University, 42003, Konya, Turkey; E-Mail: acelebi@selcuk.edu.tr

* Author to whom correspondence should be addressed; E-Mail: alikahraman@selcuk.edu.tr; Tel.: +90-332-223-33-23; Fax: +90-241-21-79.

\begin{abstract}
In this research, a water-water heat pump system using waste water as a heat source, a type that is not often used in Turkey and the World, was experimentally modeled. The experiments were performed under the conditions of simulated waste water temperature values of $20^{\circ} \mathrm{C}, 30{ }^{\circ} \mathrm{C}$ and $40{ }^{\circ} \mathrm{C}$. Inlet and outlet water temperatures of the evaporator and condenser, water flow rates in the evaporator and condenser circuits, pressures at the compressor inlet and outlet and power consumption of the system were measured. The heating coefficients of performance were calculated based on the measurements. It was found that the maximum temperature in the energy storage tank was about $50.6{ }^{\circ} \mathrm{C}$. For the heat source temperatures of $20{ }^{\circ} \mathrm{C}, 30{ }^{\circ} \mathrm{C}$ and $40{ }^{\circ} \mathrm{C}$, the heating coefficients of the performance of the system became 3.36, 3.43 and 3.69, respectively, 6 min. after the start time of the experiments and then they were decreased to $1.87,1.83$ and 1.77 with increasing water temperature in the condenser tank. The mean uncertainty value of the measurement parameters was found to be about $\pm 2.47 \%$. Finally, for the purpose of meeting hot water need as well as floor heating system requirements, it is seen that energy quality level of a waste low grade temperature heat source can be increased by using a heat pump system.
\end{abstract}

Keywords: waste heat; water-water heat pump; $\mathrm{COP}_{\text {heat }}$; energy enhancement 


\section{Introduction}

Heat pump systems are energy-efficient devices for heating and cooling of buildings. Thermal characteristics of the heat source-sink used directly affect the technical and economic performance of heat pumps. Commonly used heat sources and sinks are ambient air, exhaust air, lake water, river water, ground water, earth, rock, waste water and effluent. Ambient air is free and widely available, and it is the most common heat source for heat pumps. However, the capacity and performance of airsource heat pumps decrease rapidly with decreasing ambient temperature during the heating season, and with increasing ambient temperature during the cooling season [1]. Especially in the continental climates during winter season, heat pumps cannot provide the necessary heating needed for the system requirements because of the low atmospheric air temperature and hence they may become idle during the heating season. In order to overcome this problem, heat pumps can also be used efficiently in colder climates by using some warmer waste heat source instead of the atmospheric ambient one. For example, the average wasted warm water temperature such as found in restaurants, laundries, dormitories, textile industry facilities and etc. varies in the range of $20-40{ }^{\circ} \mathrm{C}$ throughout the year. Numerous applications exist for taking advantage of the direct or indirect benefits of waste heat energy in industrial processes. Some of these implementations are about improving the quality of the waste heat at low temperatures by way of using a heat pump, since heat pumps can provide heating and cooling energy in much greater amount than their consumed energy. Also, hot water for usage in various utility needs can be produced by a heat pump. The amount of energy consumption for obtaining hot water in commercial buildings can be lower than that for heating, ventilation, and illumination, whereas it can be much more important in places providing service facilities such as restaurants, motels, hotels, and dormitories [2,3].

As known, the condensing temperature of a heat pump is about $50{ }^{\circ} \mathrm{C}$, and the temperature of domestic hot water is about $45^{\circ} \mathrm{C}$. So, proper recovery of waste condensing heat to produce domestic hot water is an efficient means of comprehensive energy utilization [4]. The development of a heat pump system with domestic hot water is of great potential to save energy and decrease thermal pollution (i.e., global warming). Therefore, since the 1950's many researchers have conducted a lot of theoretical and experimental studies regarding the mechanics, thermodynamics analysis, cooling fluids (i.e., refrigerants), control systems, and economics of the hot water producing of the heat pumps systems [5-7].

Recently, Hepbasli and Kalinci [8] have compiled the comprehensive study regarding the hot water production by means of heat pump systems with air, ground or solar energy supported heat sources. Doğan [9] analyzed a water-water heat pump using waste water as a heat source for a hotel in Antalya, Turkey. During the cooling period (i.e., the summer season), the energy rejected from the condenser was used to produce hot water. On the other hand, during the heating period (i.e., the winter season), sea water was used as a heat source for the purpose of space heating and hot water production. In his study, it was stated that energy savings for cooling and hot water production were found to be $16 \%$ and $75 \%$, respectively. Moreover, the energy savings for the space heating in the sea water heat source case was $34 \%$ when compared with an air source heat pump system.

Baek et al. [10] also designed and analyzed a heat pump that utilized waste water discharged from the hotel sauna as a heat source for the purpose of meeting the hot water needs of the hotel. They 
showed that the hot water requirement of the hotel, except on weekends, could be met by this system during the winter season. The mean coefficient of the performance of the heat pump was found to be 4.8. Their application showed the usability of the heat pumps for the provision of the hot water in regions like Korea.

Phetteplace [11] investigated the feasibility of heat recovery from primary waste water using heat pumps. Various heat sources for heat pumps in buildings as well as in industry were discussed by Berntsson [12]. Water-source heat pump systems, which are now considered a viable alternative to conventional cooling and heating systems, have attractive performance characteristics when properly designed and installed [13]. They offered many performance advantages over air-source heat pumps due to the outstanding heat transfer properties of water and much more favorable temperatures of river or lake water [14]. The advantages and disadvantages of water-source heat pump systems were discussed previously by several researchers [14-16].

Although restaurants and commercial buildings all over the world discharge waste energy from various processes in the form of gas or liquid (i.e., water) that have generally higher temperature than the ambient air throughout the year, a limited number of heat pump systems utilizing waste water are available, as aforementioned. A reason of these application restrictions can be that the usage of water and other alternative sources in heat pumps are not well known, and they are notorious for being troublesome to operate. Another barrier is the lack of designers, contractors and operators who can properly design, install and operate these systems economically and reliably [1].

Recently, the problems regarding the processing of the energy sources and increasing environmental pollution caused by the energy consumption have required the efficient assessment of the present energy resources and their utilization to be as economical as possible. Efforts to reduce $\mathrm{CO}_{2}$ emissions due to energy consumption are also required in houses and buildings. Therefore, alternative energy sources or improvement methods should be utilized more actively. With the utilization of urban waste heat, heat pumps using various heat sources can, in many cases in the future, contribute to a reduction of $\mathrm{CO}_{2}$. Decreasing the energy consumption in the field of hot water production, space heating and air conditioning may significantly contribute to the energy conservation and protection of the environment from harmful emissions. The pollution from the combustion of fossil fuels may reach unacceptable levels during heating season. In this regard, the provision of thermal energy for space heating or meeting hot water requirements with a heat pump will receiving much more attention, owing to its certain advantageous over conventional heating systems.

In order to make a contribution to diminish these drawbacks, in this study, experimental modeling of a water-water heat pump system using waste water as a heat source was carried out. The main advantage of the usage of the water-water heat pump was that design and operation conditions can be satisfied anywhere in the World. A testing apparatus using refrigerant R134a and working according to the vapor compressed refrigeration cycle was designed. The performance of the system for three different waste water temperatures as a heat source and three different mass flow rates of the condenser water line was experimentally determined. 


\subsection{Comparison of the Heat Pump with the Other Energy Resources}

Nowadays, in addition to electricity, coal, diesel oil, oil fuel, natural gas, and LPG are commonly used as fuels to provide heat energy. The low burning efficiency of these fuel decreases the amount of beneficial energy. Moreover, unit prices of the fuels with respect to their thermal values are another factor affecting the unit energy cost. It is observed that this unit energy cost increases because of the additional costs caused by the problems such as transport, storage, crushing, pre-heating of the fuel, automatic control necessities of the system, storage of the solid waste etc. When the energy cost provided by the heat pump is compared with the other heat energy sources, the results with respect to heating value (unit price in Euro/MJ on 10 March 2009), efficiency and ranking is given in Table 1 [17,18]. The comparison data regarding the other energy sources was based on theoretical assumptions.

Table 1. Comparison of the energy cost of the heat pump with the other energy resources costs.

\begin{tabular}{lccccc}
\hline Energy Resource & Low Heating Value & Unit Price & $\begin{array}{c}\text { Efficiency } \\
\text { or COP }_{\text {heat }}\end{array}$ & $\begin{array}{c}\text { Unit Price } \\
\text { (Euro/MJ) }\end{array}$ & Ranking \\
\hline Heat Pump & $3598.24 \mathrm{~kJ} / \mathrm{kWh}$ & $0.1108 \mathrm{Euro} / \mathrm{kWh}$ & $2.61^{*}$ & 0.0118 & 1 \\
Natural Gas & $34518 \mathrm{~kJ} / \mathrm{m}^{3}$ & $0.406 \mathrm{Euro} / \mathrm{m}^{3}$ & 0.91 & 0.0129 & 2 \\
Lignite Coal & $18773.61 \mathrm{~kJ} / \mathrm{kg}$ & $0.149 \mathrm{Euro} / \mathrm{kg}$ & 0.60 & 0.0133 & 3 \\
Imported Coal & $29288 \mathrm{~kJ} / \mathrm{kg}$ & $0.281 \mathrm{Euro} / \mathrm{kg}$ & 0.65 & 0.0147 & 4 \\
Oil Fuel & $41317 \mathrm{~kJ} / \mathrm{kg}$ & $0.668 \mathrm{Euro} / \mathrm{kg}$ & 0.80 & 0.0202 & 5 \\
Electricity & $3598.24 \mathrm{~kJ} / \mathrm{kWh}$ & $0.1108 \mathrm{Euro} / \mathrm{kWh}$ & 0.99 & 0.0311 & 6 \\
LPG (Propane) & $46442.4 \mathrm{~kJ} / \mathrm{kg}$ & $1.394 \mathrm{Euro} / \mathrm{kg}$ & 0.92 & 0.0326 & 7 \\
Diesel Oil & $42911 \mathrm{~kJ} / \mathrm{kg}$ & $1.185 \mathrm{Euro} / \mathrm{kg}$ & 0.84 & 0.0329 & 8 \\
\hline
\end{tabular}

$* \mathrm{COP}_{\text {heat }}$ was taken from the present research result as a mean heating coefficient performance.

\section{Materials and Methods}

The schematic diagram of the water-water heat pump designed in this study for the aim of waste heat recovery is illustrated in Figure 1. The main components of the heat pump system are the compressor, condenser, evaporator and expansion valve. The operation principle of the system is as follows: in an ideal vapor-compression refrigeration cycle, the refrigerant enters the compressor as saturated vapor and is compressed isentropically to the condenser pressure. In fact, the refrigerant is slightly superheated at the compressor inlet to ensure that the refrigerant is completely vaporized when it enters the compressor [19]. The temperature of the refrigerant increases during this isentropic compression process to well above the temperature of the hot water (i.e., heat storage tank). The refrigerant then enters the condenser as superheated vapor and leaves it as a saturated liquid because of heat rejection to the circulating water. The temperature of the refrigerant at this situation is still above the temperature of the surrounding water. The rejected heat is conveyed to the storage tank as heat energy by means of the circulation pump. The refrigerant is subcooled somewhat before it enters the throttling valve so that the refrigerant in this case enters the evaporator with a lower enthalpy and thus it can absorb more heat from the waste water source. The saturated liquid refrigerant is throttled to the 
evaporator pressure by passing it through an expansion valve. The refrigerant temperature drops below the waste water temperature during this process. The refrigerant enters the evaporator as a low-quality saturated mixture, and it completely evaporates by absorbing heat from the heat source. The refrigerant leaves the evaporator as saturated vapor and reenters the compressor to complete the cycle.

Figure 1. Schematic diagram of experimental rig of the heat pump system.

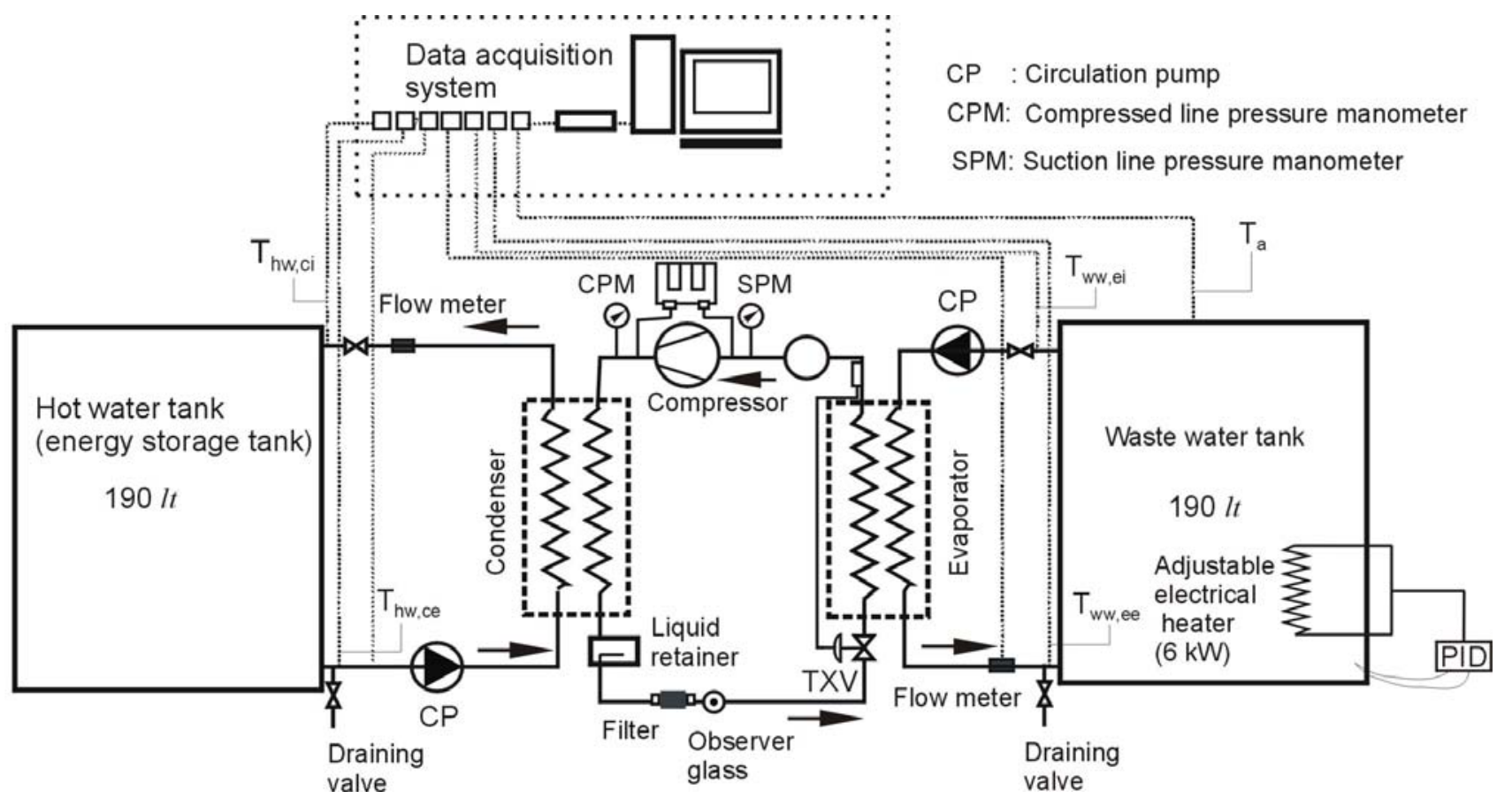

A hermetic compressor with a power of $1,472 \mathrm{~W}$ is utilized in the system. The evaporator and condenser capacities of the system were $6,000 \mathrm{~W}$ and 7,500 W, respectively. The evaporator and condenser of the heat pump are plate type heat exchangers and their heat transfer surface areas were $0.42 \mathrm{~m}^{2}$ and $0.72 \mathrm{~m}^{2}$, respectively. An external compensated thermostatic valve was also used in the system. The refrigerant used in the system was $\mathrm{R} 134 \mathrm{a}\left(\mathrm{CH}_{2} \mathrm{FCF}_{3}\right.$ - tetrafluoroethane) that does not harm the environment. Two separate $190 \mathrm{~L}$ capacity storage tanks insulated with $50 \mathrm{~mm}$ cotton wool material having thermal conductivity of $0.035 \mathrm{~W} / \mathrm{mK}$ were used as heat sink and source. Two transport water circuits that have three different circulation pump flow rates from evaporator to the storage tank (i.e., heat source) and from condenser to the storage tank (i.e. heat sink) were used. The source was simulated as waste heat source by keeping the water temperature approximately at fixed values of $20{ }^{\circ} \mathrm{C}, 30{ }^{\circ} \mathrm{C}$, and $40{ }^{\circ} \mathrm{C}$ during the experiments. Actually, these waste water temperature values represent the discharged water temperature of a dormitory located on the campus of Selçuk University. There are two insulated hot water tanks with a capacity of $10 \mathrm{~m}^{3}$. A liquid retainer to prevent the return of the liquid refrigerant to the compressor, a presostat to protect the compressor, a sight glass to observe the physical conditions of the cooling fluid at the condenser exit and two manometers at the inlet and outlet lines of the compressor to measure the pressures were used in the system. The waste heat source temperature in the water tank was kept almost constant by using three electrical heaters with $2 \mathrm{~kW}$ power capacities. The operation of the heaters was controlled by means of a proportional- 
integral-derivative (PID) temperature controller. Temperature measurement sensors were attached to the water inlet and outlet lines of the waste heat tank.

Heat output capacity of the condenser (i.e., transferred heat rate to the hot water tank) was determined from the temperature and flow rate measurements of the hot water. Water temperature differences between the inlet and outlet of the condenser and evaporator were measured using K-type thermocouples inserted into the water line circuits. Volumetric flow rates of the water flowing through the system were measured with two turbine flow meters (Sika-VTH model) with an accuracy of $\pm 10^{-3}$, one at the outlet of the evaporator and the other one at the outlet of the condenser in the waste and hot water circuits.

The performance of a heat pump is expressed in terms of the coefficient of performance. The performance value of the heat pump can be found experimentally with the help of the temperature differences of the inflowing and out-flowing fluids for the evaporator or condenser, and mass flow rates of the transport fluids. Heating coefficients of performances $\left(\mathrm{COP}_{\text {heat }}\right)$ of the modeled heat pump at three different temperatures of the waste water sources and three different mass flow rates of hot water were calculated.

The heating capacity and heating coefficient of performance of the heat pump were calculated, respectively, from the following equations:

$$
\begin{gathered}
O_{c}=m_{h w} c_{p}\left(T_{h w, c i}-T_{h w, c e}\right) \\
C O P_{\text {heat }}=\frac{O_{c}}{W_{\text {tot }}}=\frac{m_{h w} c_{p}\left(T_{h w, c i}-T_{h w, c e}\right)}{W_{c o m p}+W_{p u m p s}}
\end{gathered}
$$

where $Q_{c}$ is the rate of the heat transfer that has been removed from the condenser. $W_{\text {tot }}$ is the total power consumption of the system. $m_{h w}$ and $c_{p}$ show, respectively, mass flow rate of the hot water and specific heat of water. $T_{h w, c i}$ and $T_{h w, c e}$ represent, respectively, the temperature of the hot water at the condenser inlet and exit. For this approach, assumptions in the condenser heat exchanger for Eqn.1 are negligible heat loss to the surroundings, negligible kinetic and potential energy changes, constant properties at the mean temperature of inlet and outlet, steady-flow rate (i.e., steady operating conditions exist). Under these assumptions, the first law of thermodynamics requires that the rate of heat transfer from the hot fluid be equal to the rate of heat transfer to the cold one.

It should be noted that, in Equation 2, $W_{\text {tot }}$ includes the power to the pumps ( $\left.W_{\text {pumps }}\right)$ used for circulation of the hot water and the power consumption of the compressor $\left(W_{\text {comp }}\right)$ of the heat pump. However, it does not include the energy consumption of the heaters and the PID temperature controllers used waste water tank.

Experiments were conducted for three different speeds of the recirculation pump between the hot water tank and condenser. The mass flow rate of waste water was kept fixed in all experiments. Total experiment duration was taken as 90 minutes, which is suitable time for the system working temperature limits with respect to the tank capacity. The measurements of the parameters for the temperature of the water at the inlet and outlet of the condenser, the temperature of the waste water at the inlet and outlet of the evaporator, mass flow rate of the waste water at the inlet of the evaporator, suction and compressed line pressures for the compressor, and the energy consumed by the system 
were recorded for every three minutes period during the experiments. So, the measured and given values in the graphics represent the mean values along the three minutes.

\section{Results and Discussion}

Experimental modeling of water-water heat pump systems using waste water as the heat source was carried out. A testing apparatus using R134a refrigerant and working according to the vapor compressed refrigeration cycle was designed. The performance of the system for three different temperatures for the waste water heat source and three different fixed water flow rates was experimentally determined. Different pump flow rates were presented as CP I, CP II and CP III. The mass flow rates of the hot water used for utilization purposes for these flow rates of the pump according to the different waste water temperatures were given in Table 2.

Table 2. Mass flow rates of the utilization hot water according to the circulation pump speeds.

\begin{tabular}{cccc}
\hline $\begin{array}{c}\text { Mass flow rates of the } \\
\text { circulation pump }\end{array}$ & $\begin{array}{c}\left.m_{h w} \mathbf{( k g} / \mathbf{s}\right) \\
\left.\text { (for } \mathbf{2 0}{ }^{\circ} \mathrm{C}\right)\end{array}$ & $\begin{array}{c}m_{h w}(\mathbf{k g} / \mathbf{s}) \\
\left.\text { (for } \mathbf{3 0}{ }^{\circ} \mathrm{C}\right)\end{array}$ & $\begin{array}{c}m_{h w}(\mathbf{k g} / \mathbf{s}) \\
\left.\text { (for } \mathbf{4 0}{ }^{\circ} \mathrm{C}\right)\end{array}$ \\
\hline$C P I$ & 0.131 & 0.144 & 0.158 \\
$C P I I$ & 0.152 & 0.190 & 0.207 \\
$C P$ III & 0.196 & 0.226 & 0.224 \\
\hline
\end{tabular}

The changes in the temperature of the hot water at the inlet and outlet of the condenser, for the three different flow rates of the circulation pump for the situations of waste water temperature values of $20^{\circ} \mathrm{C}, 30^{\circ} \mathrm{C}$, and $40{ }^{\circ} \mathrm{C}$ are depicted in Figures $2-4$. Maximum temperature difference between the inlet and outlet of the condenser for the lowest flow rate of the circulation pump occurred as $7.5^{\circ} \mathrm{C}$. When the waste water source temperature was taken as $20^{\circ} \mathrm{C}$ and the circulation pumps were operated with the highest flow rate, the temperature difference became $3.3{ }^{\circ} \mathrm{C}$. Likewise, the maximum temperature difference was $7.6^{\circ} \mathrm{C}$ under the condition of the lowest flow rate of the circulation pump and a waste water source temperature of $30^{\circ} \mathrm{C}$. When temperature of the waste water source increase to $40{ }^{\circ} \mathrm{C}$, the maximum temperature difference increased very little and was $7.8^{\circ} \mathrm{C}$ for the lowest flow rate of the circulation pump. A temperature difference of $3.4^{\circ} \mathrm{C}$ was recorded for the highest flow rate of the circulation pump, even if the waste water source temperature increased from $30{ }^{\circ} \mathrm{C}$ to $40{ }^{\circ} \mathrm{C}$. Moreover, it is observed in Figure 4 that the difference in the curve corresponding to the change of temperature with time is at a minimum for the lowest mass flow rate of the circulation pump. As seen from Figure 2, the temperature differences for waste water temperatures of $20{ }^{\circ} \mathrm{C}$ were, in sequence, $7.5^{\circ} \mathrm{C}, 6.6^{\circ} \mathrm{C}$ and $5.2^{\circ} \mathrm{C}$ for $C P I, C P I I$ and $C P I I I$ at the 6 th min of the experiment and then they were recorded as $5{ }^{\circ} \mathrm{C}, 4.2^{\circ} \mathrm{C}$ and $3.3^{\circ} \mathrm{C}$ at 90 th min of the experiment. Similar trends can also be observed in Figures 3 and 4 and their values were decreased from $7.6{ }^{\circ} \mathrm{C}$ to $3.4{ }^{\circ} \mathrm{C}$ and from $7.8{ }^{\circ} \mathrm{C}$ to $3.4{ }^{\circ} \mathrm{C}$, respectively. 
Figure 2. The variation of the temperature at the inlet and outlet of the condenser along the experiment according to the circulation pump flow rates at fixed waste water temperature of $20^{\circ} \mathrm{C}$.

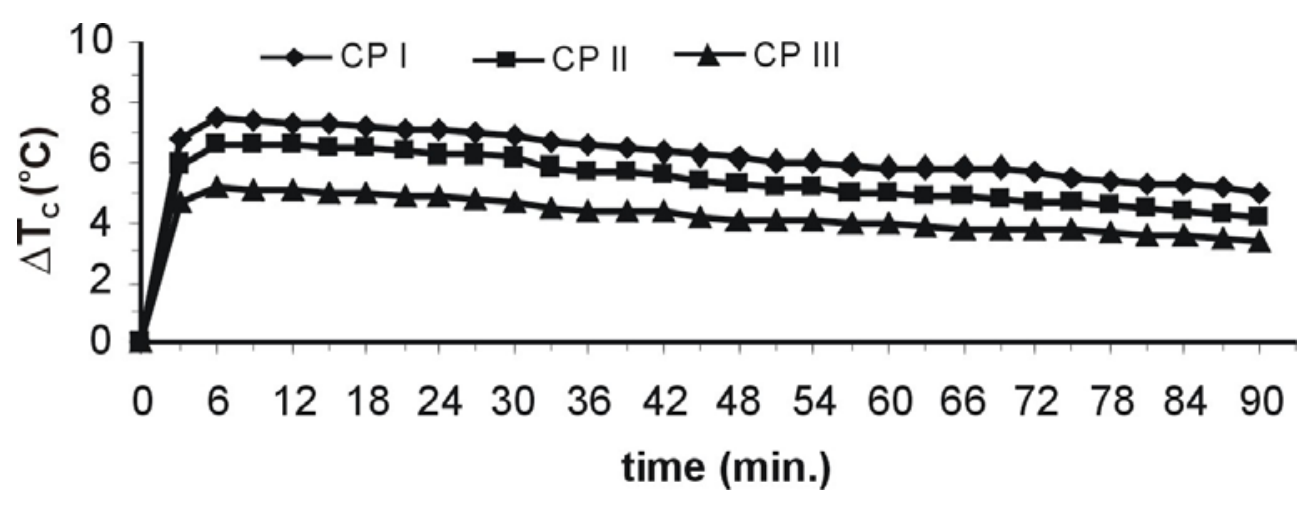

Figure 3. The variation of the temperature at the inlet and outlet of the condenser along the experiment according to the circulation pump flow rates at fixed waste water temperature of $30^{\circ} \mathrm{C}$.

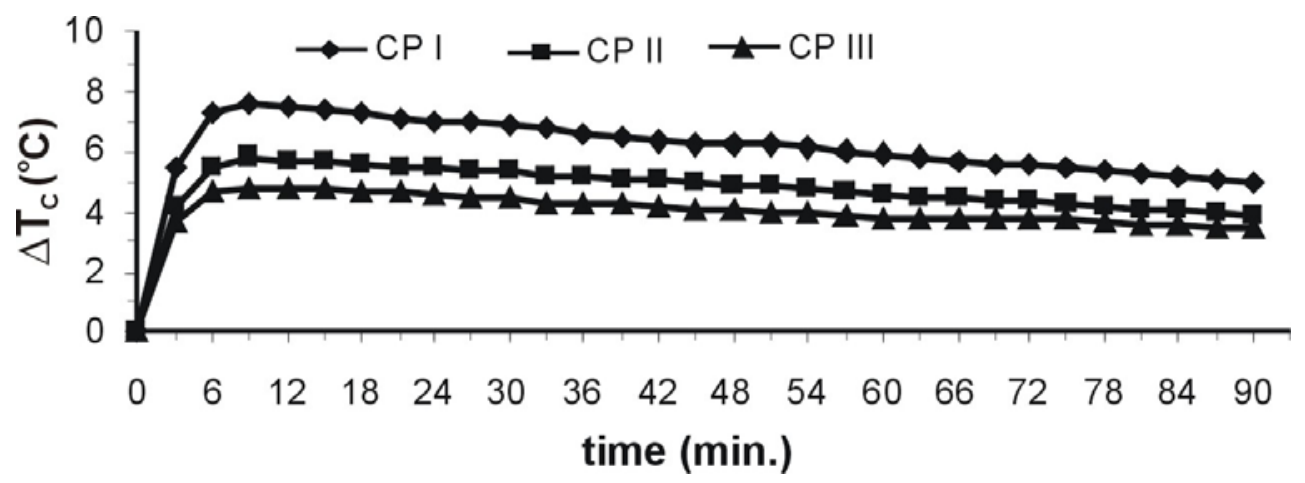

Figure 4. The variation of the temperature at the inlet and outlet of the condenser along the experiment according to the circulation pump flow rates at fixed waste water temperature of $40{ }^{\circ} \mathrm{C}$.

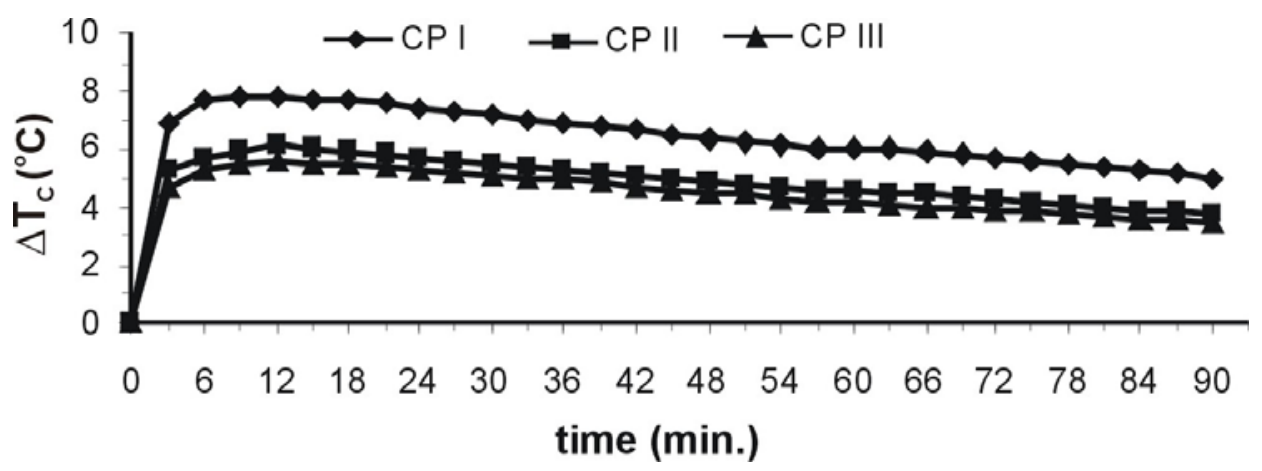

The temperature variations of the waste water heat source during the experiments are illustrated in Figure 5. As seen from this figure, they were successfully kept almost constant as $20{ }^{\circ} \mathrm{C}, 30{ }^{\circ} \mathrm{C}$, and $40{ }^{\circ} \mathrm{C}$ by means of the PID control system. 
Figure 5. The variation of the waste water temperature for the circulation pump flow rate $C P I$ during the experiment.

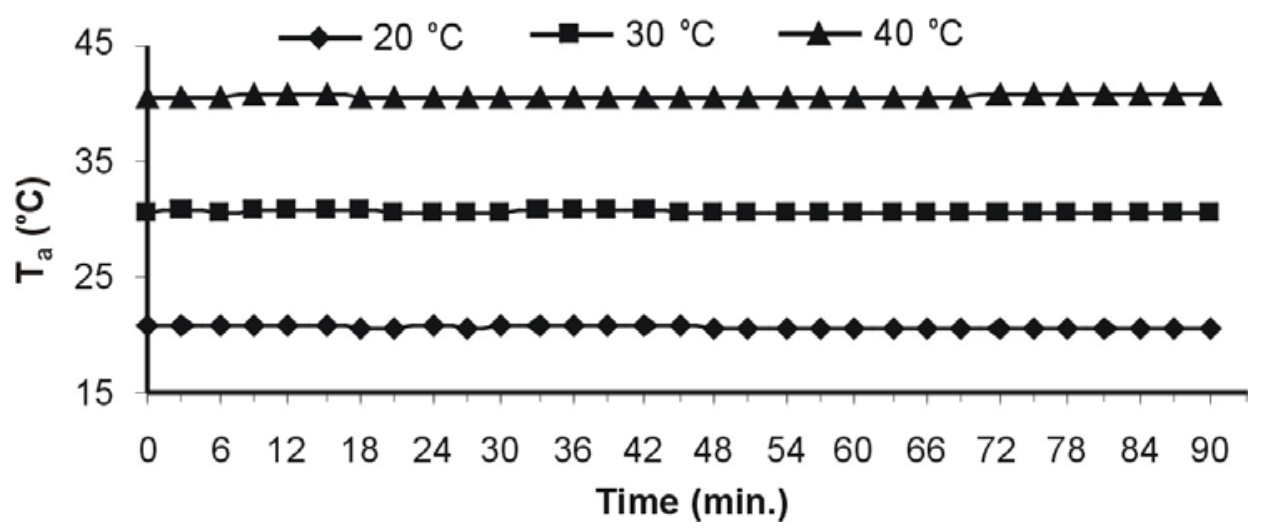

The variation of the temperatures in the hot water tank during the experiment at the lowest flow rate $(C P I)$ for the waste water temperature values of $20{ }^{\circ} \mathrm{C}, 30{ }^{\circ} \mathrm{C}$, and $40{ }^{\circ} \mathrm{C}$ is depicted in Figure 6 . The initial temperature of the condenser heat rejection (i.e. energy storage) tank for all cases was taken as $15{ }^{\circ} \mathrm{C}$. As the heat pump system works and discharges heat energy to the storage tank, hot water temperatures reach $49.4{ }^{\circ} \mathrm{C}, 51.2{ }^{\circ} \mathrm{C}$, and $55.6{ }^{\circ} \mathrm{C}$ for the waste water temperature values of $20{ }^{\circ} \mathrm{C}, 30{ }^{\circ} \mathrm{C}$, and $40{ }^{\circ} \mathrm{C}$, respectively. All of these the results show that the quality of the waste water temperature improve approximately $150 \%$ (i.e., $\left.\left(\left(49.4{ }^{\circ} \mathrm{C}-20{ }^{\circ} \mathrm{C}\right) / 20{ }^{\circ} \mathrm{C}\right) \times 100 \% \cong 150 \%\right), 70 \%$ and $40 \%$ for $20{ }^{\circ} \mathrm{C}, 30{ }^{\circ} \mathrm{C}$, and $40{ }^{\circ} \mathrm{C}$, respectively. The water having this kind of high level temperatures can be utilized for floor heating systems in buildings and the produced hot water can be used to meet the demand for hot water needs of laundry, dishwashing, bathing and showering purposes, etc.

The changes of the pressures at the inlet and outlet of the compressor are shown in Figure 7. The suction line pressures at the compressor inlet were, respectively, recorded as 1.8, 1.9 and 2.0 bar for the waste water temperatures of $20{ }^{\circ} \mathrm{C}, 30^{\circ} \mathrm{C}$, and $40{ }^{\circ} \mathrm{C}$. On the other hand, due to increasing water temperature in the storage tank by time the compressed line pressures at the compressor outlet were, respectively, changed from 5.5 to 12.8 bar, 5.5 to 14.1 and 5.5 to 15.2 bar for the waste water temperatures of $20{ }^{\circ} \mathrm{C}, 30{ }^{\circ} \mathrm{C}$, and $40{ }^{\circ} \mathrm{C}$. As expected, the highest outlet pressure occurred for the condition of the highest waste water source temperature. Likewise, the change in the heat rejection amount from the condenser is given in Figure 8. With the increasing time along the experiment for the condition of the constant mass flow rate of the circulation pump at $C P I$, decreasing water temperature differences between the inlet and outlet of the condenser as a conclusion of increasing temperature in the storage tank and increasing pressure at the compressor outlet result in a continuous decrease in the heat transfer rate due to the thermodynamic cycle properties. As seen from Figure 8, the amount of the discharged heat from the condenser decreased from $4,499 \mathrm{~W}$ to $3,157 \mathrm{~W}$ at the waste water temperature of $40^{\circ} \mathrm{C}$. 
Figure 6. The change in the domestic hot water temperature in the storage tank along the experiment for the circulation pump flow rate $C P I$.

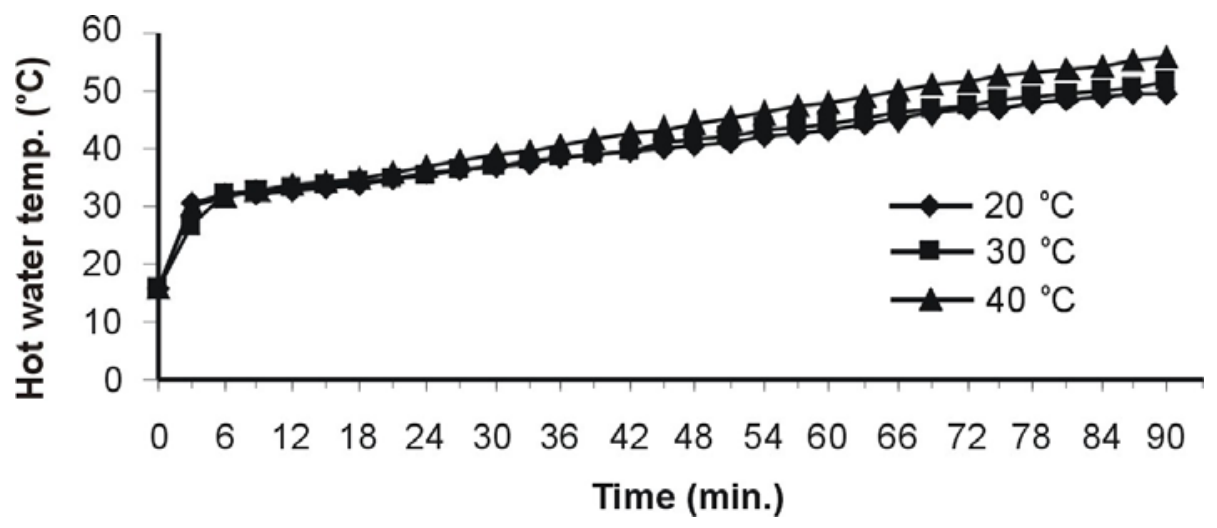

Figure 7. Pressure changes at the inlet and outlet of the compressor along the experiment for the circulation pump flow rate $C P I$.

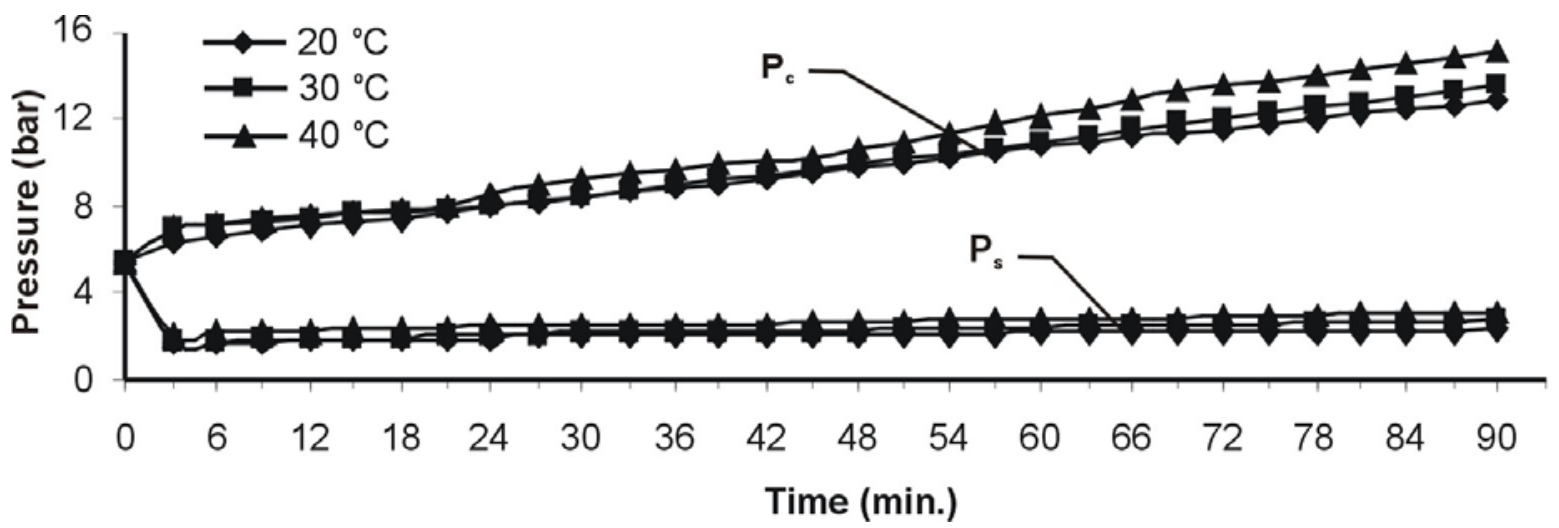

Figure 8. The change in the heat amount discarded from the condenser along the experiment for the circulation pump flow rate $C P I$.

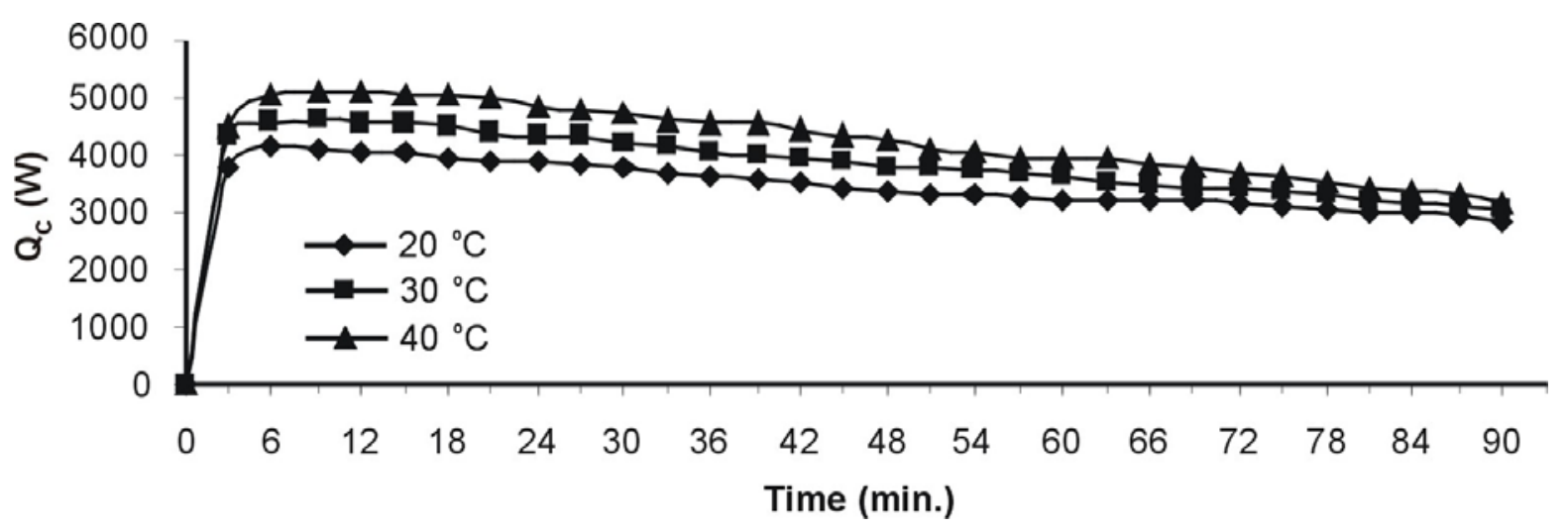

The changes in the heating coefficients of performance $\left(\mathrm{COP}_{\text {heat }}\right)$ during the experiment at three different waste water temperatures for different flow rate values of the circulation pump are presented in Figures 9-11. The $\mathrm{COP}_{\text {heat }}$ was observed to be increasing at the $6^{\text {th }}$ and $9^{\text {th }}$ minutes and then decreasing after this time to about 1.80. The $\mathrm{COP}_{\text {heat }}$ values were observed to be increasing, even if just 
by a little amount, when the temperatures of the waste water source temperature increased for all of the flow rates of the circulation pumps. This situation can be attributed to the decrease in the amount of heat transfer rate due to the decrease in the temperature difference between the hot water inlet and outlet temperatures of the condenser and the increase in the electrical energy consumption in the system with the increase in the pressure of the compressor outlet. The $\mathrm{COP}_{\text {heat }}$ maximum values were reached at the $6^{\text {th }} \mathrm{min}$. for every situation when the waste water and utilization water temperatures were constant. The $\mathrm{COP}_{\text {heat }}$ values decreased to from 3.34, 3.51 and 3.77 to $1.87,1.83$, and 1.77 values for $20{ }^{\circ} \mathrm{C}, 30{ }^{\circ} \mathrm{C}$, and $40{ }^{\circ} \mathrm{C}$ waste water temperatures, respectively, with the increase in the temperature of the condenser tank. Maximum heating coefficient of performance was found as 3.77 for the highest flow rate of the circulation pump and $40{ }^{\circ} \mathrm{C}$ of waste water temperature value. On the other hand, the minimum $\mathrm{COP}_{\text {heat }}$ value was determined as 1.77 for the highest cycle value of the circulation pump and $40{ }^{\circ} \mathrm{C}$ of waste water temperature at the end of the experiment.

Time averaged mean $\mathrm{COP}_{\text {heat }}$ values were obtained as $2.53,2.60$, and 2.65 for the waste water temperature values of $20^{\circ} \mathrm{C}, 30^{\circ} \mathrm{C}$, and $40{ }^{\circ} \mathrm{C}$ for the circulation pump flow rate $C P$ III in Figure 11 . The other parameters are summarized in Table 3 . The change in time averaged mean of the heating coefficients of performance according to the circulation pump flow rates was shown in Figure 12. The differences in the $\mathrm{COP}_{\text {heat }}$ values according to the mass flow rates were found to be the most at $20{ }^{\circ} \mathrm{C}$ waste water source temperature. As the waste water temperature values were taken as $30{ }^{\circ} \mathrm{C}$ and $40{ }^{\circ} \mathrm{C}$, the difference between the mean $\mathrm{COP}_{\text {heat }}$ values are negligible.

Figure 9. The variation of the heating coefficients of performance at the different waste water temperatures for the circulation pump flow rate $C P I$ during the experiment.

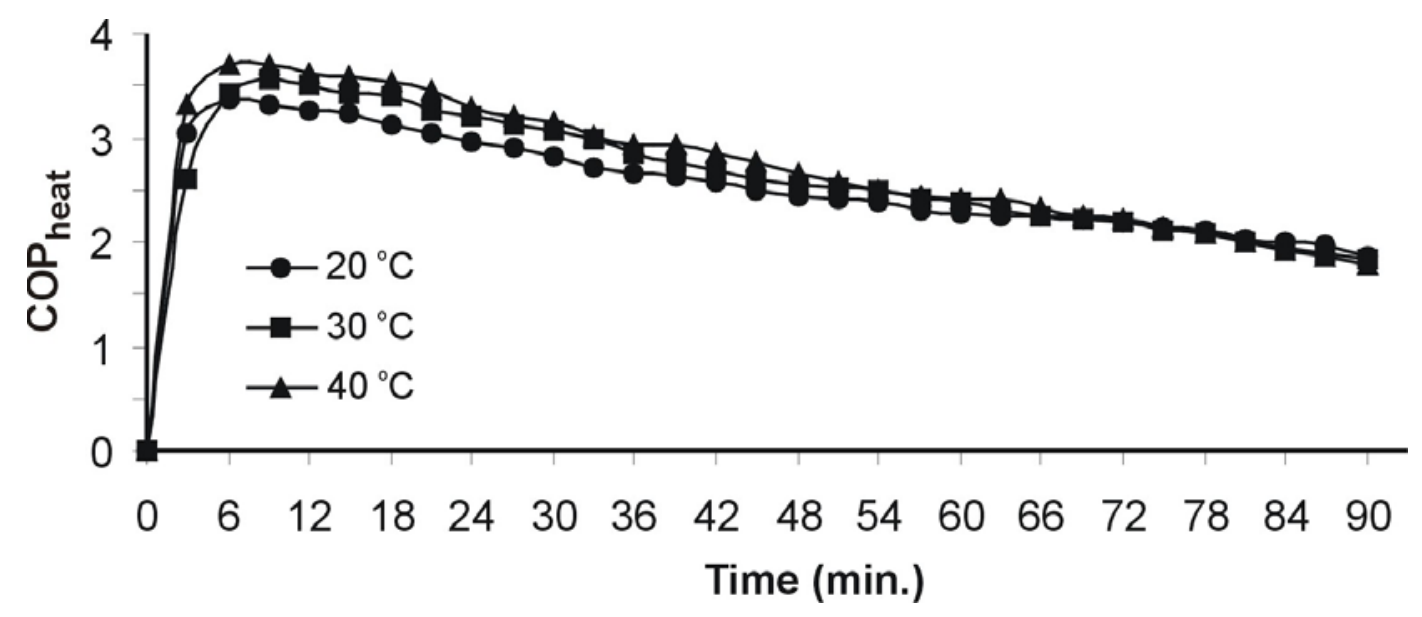


Figure 10. The variation of the heating coefficients of performance at the different waste water temperatures for the circulation pump flow rate $C P I I$ during the experiment.

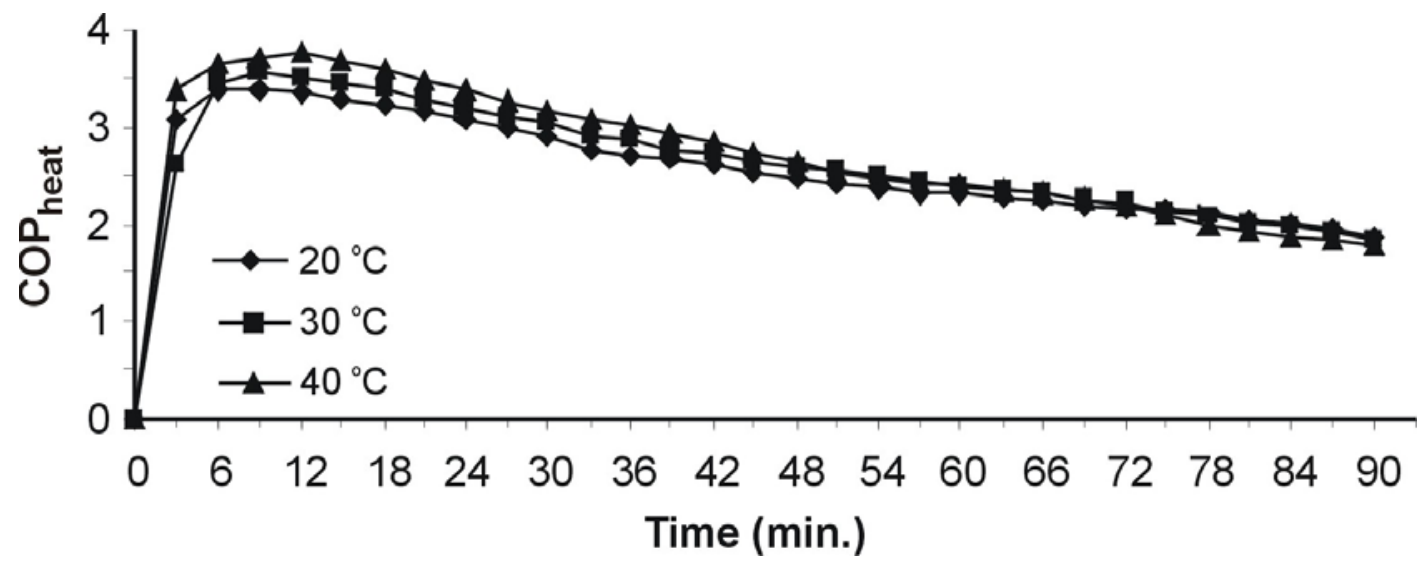

Figure 11. The variation of the heating coefficients of performance at the different waste water temperatures for the circulation pump flow rate $C P I I I$ during the experiment.

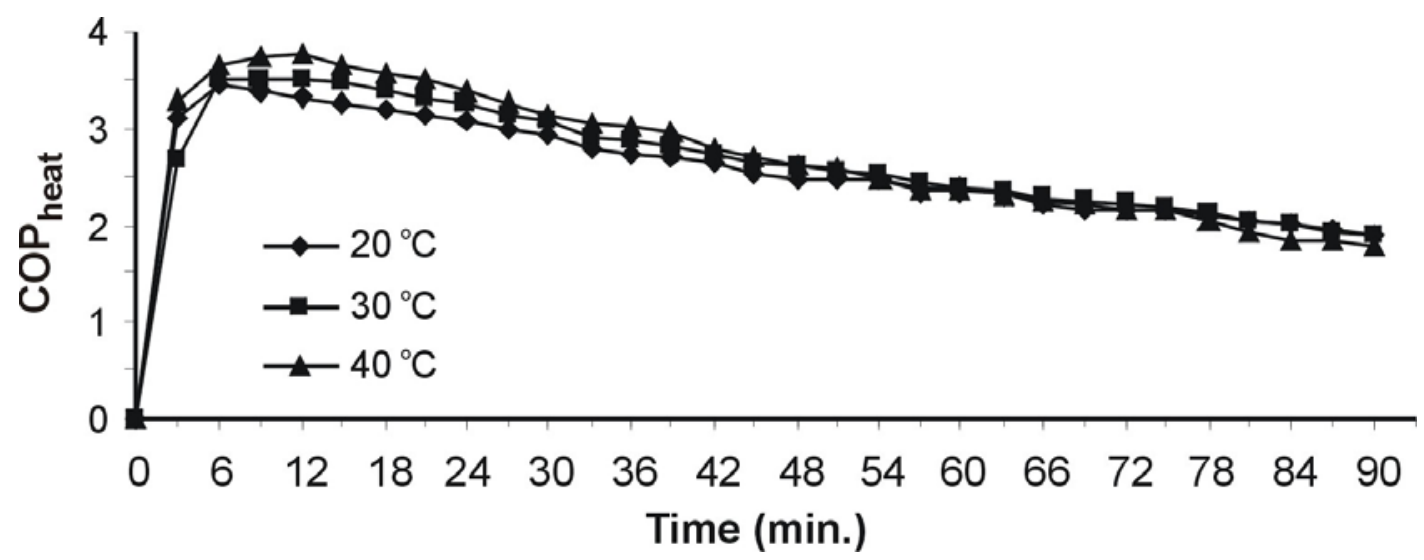

Figure 12. The variation of time averaged heating coefficients of performance according to the circulation pump flow rates.

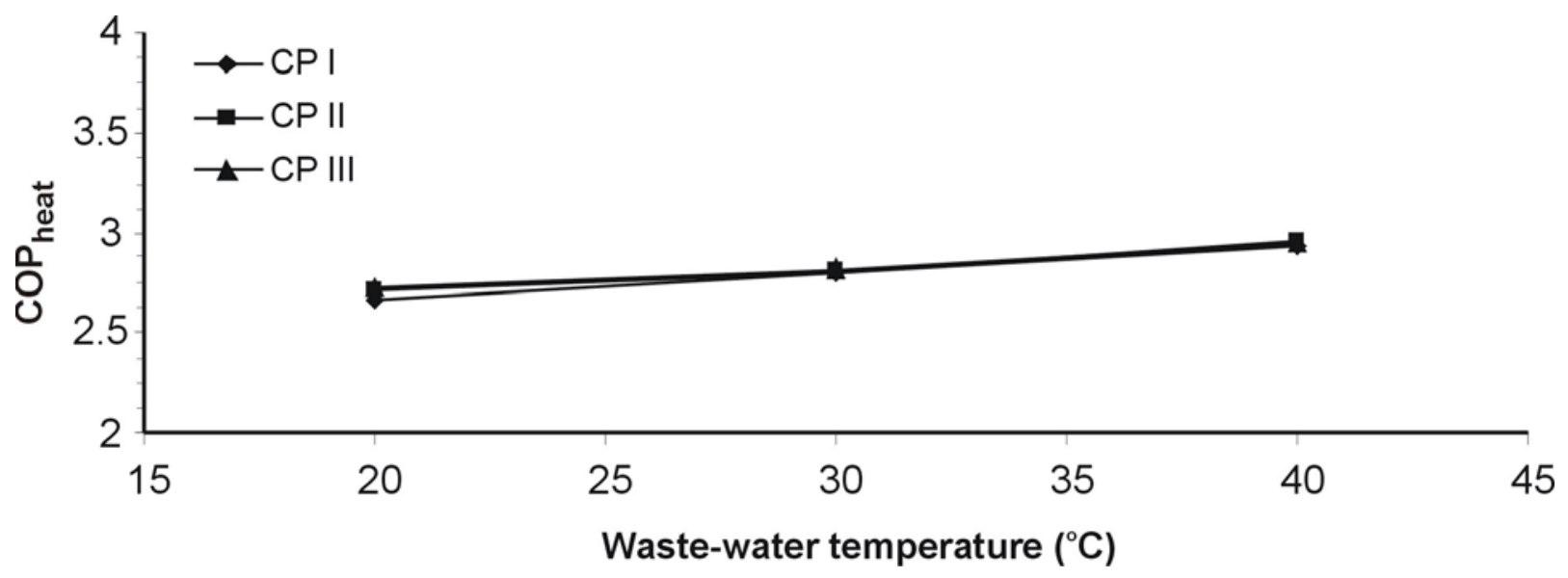


Figure 12 shows the mean $\mathrm{COP}_{\text {heat }}$ values obtained from the experiments performed with various waste water temperatures. As expected, with the increase of waste water temperature $\left(T_{\mathrm{a}}\right)$, the $\mathrm{COP}_{\text {heat }}$ increases. A least-square, linear curve fit to the data points yields the following equation:

$$
C O P_{\text {heat }}=2.365+0.007 T_{a}
$$

where $T_{\mathrm{a}}$ is in ${ }^{\circ} \mathrm{C}$. It can be stated that Equation 3 can be used anywhere in the World for the similar experiment or application conditions. The mean $\mathrm{COP}_{\text {heat }}$ increases as the waste water temperatures increases according to the Equation 3.

\subsection{Uncertainty Analysis}

Any experimental result involves some level of uncertainty that may originate from causes such as the lack of accuracy in measurement equipments and approximations in data reduction relations. These individual inaccuracies eventually translate into uncertainty in the final results. Kanoglu [20] presents a detailed example of such an analysis. Consider the result, $\mathrm{F}$, to be a function of $\mathrm{n}^{\text {th }}$ measured variables $\mathrm{x}_{1}, \mathrm{x}_{2}, \ldots, \mathrm{x}_{\mathrm{n}}$ as:

$$
F=f\left(x_{1}, x_{2}, \ldots \ldots \ldots \ldots \ldots x_{n}\right)
$$

The maximum uncertainty estimation in $\mathrm{R}$ can be expressed by the relation given by Wheeler and Ganji [21] as:

$$
W_{F, \max }=\sum_{i=1}^{n}\left|W_{x i} \frac{\partial R}{\partial x i}\right|
$$

where all terms are assumed positive. A better estimate for uncertainty is given by:

$$
W_{R}=\left[\sum_{i=l}^{n}\left(W_{x i} \frac{\partial F}{\partial x i}\right)^{2}\right]^{1 / 2}
$$

where $W_{x i}$ is the accuracy or error of the measured parameter. It is important that all uncertainties used in Equation 6 be evaluated at the same confidence level. The uncertainty estimate in the $\mathrm{COP}_{\text {heat }}$ that is given with Equation 2 can be calculated from Eqn. 6 as follows:

$$
W_{\text {COP heat }}=\left[\begin{array}{l}
\left(W_{\dot{V}_{h w}} \frac{\partial C O P_{\text {heat }}}{\partial \dot{V}_{h w}}\right)^{2}+\left(W_{\rho_{h w}} \frac{\partial C O P_{\text {heat }}}{\partial \rho_{h w}}\right)^{2}+\left(W_{T h w, c i} \frac{\partial C O P_{\text {heat }}}{\partial T_{h w, c i}}\right)^{2}+ \\
\left.\left(W_{\text {Thw,ce }} \frac{\partial C O P_{\text {heat }}}{\partial T_{h w, c e}}\right)^{2}+\left(W_{W \text { comp }} \frac{\partial C O P_{\text {heat }}}{\partial W_{\text {comp }}}\right)^{2}+\left(W_{W_{\text {pumps }}} \frac{\partial C O P_{\text {heat }}}{\partial W_{\text {pumps }}}\right)^{2}\right]^{1 / 2}
\end{array}\right.
$$

The $\mathrm{COP}_{\text {heat }}$ values were determined from the measurement and taken physical properties from the tables. Measurement and reading accuracies of the variables that were taken into account to calculate the uncertainty values are volumetric flow rate $\left( \pm 10^{-3} \mathrm{~m}^{3} / \mathrm{s}\right)$, density of the water $\left( \pm 0.01 \mathrm{~kg} / \mathrm{m}^{3}\right)$, specific heat capacity $( \pm 1 \mathrm{~kJ} / \mathrm{kgK})$, temperature difference between the inlet and outlet temperatures of 
the condenser $\left( \pm 0.1{ }^{\circ} \mathrm{C}\right)$ and total electrical energy consumption for compressor and circulation pumps in the system $( \pm 20 \mathrm{~W})$.

The uncertainty value was calculated to be the less for the lowest flow rate while it was increased with the increase in the flow rate of the circulation pump. This increase can be attributed the decrease in the water temperature difference between the inlet and outlet of the condenser due to the increase in the flow rate of the circulation pump. Moreover, an increase in the amount of electrical energy consumption of the system along the experiment gives rise to decrease the uncertainty value. The uncertainty values were calculated as $\pm 2.72 \%, \pm 2.40 \%$, and $\pm 2.31 \%$, respectively, for $20{ }^{\circ} \mathrm{C}, 30{ }^{\circ} \mathrm{C}$, and $40{ }^{\circ} \mathrm{C}$ waste water temperature values for the lowest flow rate of circulation pump. These values were $\pm 2.73 \%, \pm 2.99 \%$, and $2.95 \%$ for circulation pump flow rate CP II whereas the same values were calculated as $\pm 3.42 \%, \pm 3.53 \%$, and $\pm 3.21 \%$ for the highest flow rate $C P$ III. The overall evaluation of the main findings from the experiments is summarized in Table 3.

Table 3. The change and evaluation of the parameters for different pump flow rates duration $90 \mathrm{~min}$.

\begin{tabular}{|c|c|c|c|c|c|c|}
\hline $\begin{array}{c}\text { Pump } \\
\text { flow rate }\end{array}$ & $\mathrm{Ta}=20^{\circ} \mathrm{C}$ & $\mathbf{T a}=30^{\circ} \mathrm{C}$ & $\mathrm{Ta}=40^{\circ} \mathrm{C}$ & $\mathrm{Ta}=20^{\circ} \mathrm{C}$ & $\mathrm{Ta}=30^{\circ} \mathrm{C}$ & $\mathrm{Ta}=40^{\circ} \mathrm{C}$ \\
\hline & $\begin{array}{c}C O P_{\text {heat }} \\
\left(\mathrm{COP}_{\text {heat-ave }}\right)\end{array}$ & $\begin{array}{c}C O P_{\text {heat }} \\
\left(\mathrm{COP}_{\text {heat-ave }}\right)\end{array}$ & $\begin{array}{c}C O P_{\text {heat }} \\
\left(\mathrm{COP}_{\text {heat-ave }}\right)\end{array}$ & $\operatorname{Thw}\left({ }^{\circ} \mathrm{C}\right)$ & $\operatorname{Thw}\left({ }^{\circ} \mathrm{C}\right)$ & $\operatorname{Thw}\left({ }^{\circ} \mathrm{C}\right)$ \\
\hline CP I & $\begin{array}{c}3.36-1.87 \\
(2.48)\end{array}$ & $\begin{array}{c}3.57-1.83 \\
(2.57)\end{array}$ & $\begin{array}{c}3.69-1.77 \\
(2.67)\end{array}$ & $15-44.4$ & $15-46.2$ & $15-50.6$ \\
\hline CP II & $\begin{array}{c}3.39-1.88 \\
(2.52)\end{array}$ & $\begin{array}{c}3.56-1.85 \\
(2.58)\end{array}$ & $\begin{array}{c}3.77-1.79 \\
(2.67)\end{array}$ & $15-44.5$ & $15-46.8$ & $15-50.2$ \\
\hline \multirow[t]{2}{*}{ CP III } & $\begin{array}{c}3.44-1.89 \\
(2.53)\end{array}$ & $\begin{array}{c}3.51-1.91 \\
(2.60) \\
\end{array}$ & $\begin{array}{c}3.75-1.77 \\
(2.65) \\
\end{array}$ & $15-44.7$ & $15-47.1$ & $15-50.4$ \\
\hline & $Q_{c}(W)$ & $Q_{c}(\mathrm{~W})$ & $Q_{c}(\mathrm{~W})$ & $P_{c}$ (bar) & $P_{c}$ (bar) & $P_{c}$ (bar) \\
\hline$C P I$ & $4,172-2,800$ & $4,575-3,031$ & $5,086-3,157$ & $5.5-12.7$ & $5.5-13.5$ & $5.5-15.1$ \\
\hline CP II & $4,202-2,826$ & $4,631-3,065$ & $5,278-3,178$ & $5.5-12.7$ & $5.5-14.0$ & $5.5-15.1$ \\
\hline \multirow[t]{2}{*}{ CP III } & $4,261-2,828$ & $4,636-3,212$ & $5,243-3,156$ & $5.5-12.8$ & $5.5-14.1$ & $5.5-15.2$ \\
\hline & $W_{t o t}(\mathrm{~W})$ & $W_{t o t}(\mathrm{~W})$ & $W_{t o t}(\mathrm{~W})$ & $\begin{array}{c}\text { Uncertainty } \\
\pm(\%)\end{array}$ & $\begin{array}{c}\text { Uncertainty } \\
\pm(\%)\end{array}$ & $\begin{array}{c}\text { Uncertainty } \\
\pm(\%)\end{array}$ \\
\hline$C P I$ & $1,240-1,500$ & $1,280-1,660$ & $1,360-1,780$ & $2.03-2.92$ & $1.99-2.91$ & $1.92-2.90$ \\
\hline CP II & $1,220-1,500$ & $1,280-1,660$ & $1,360-1,780$ & $2.24-3.42$ & $2.49-3.66$ & $2.37-3.75$ \\
\hline CP III & $1,240-1,500$ & $1,300-1,680$ & $1,360-1,780$ & $2.82-4.31$ & $2.98-4.18$ & $2.56-4.18$ \\
\hline
\end{tabular}

\section{Conclusions and Recommendations}

A water-water heat pump system was modeled and the experimental results under various conditions were evaluated. It was shown that hot water temperatures reached $49.4{ }^{\circ} \mathrm{C}, 51.2{ }^{\circ} \mathrm{C}$, and $55.6{ }^{\circ} \mathrm{C}$ for the waste water temperature values of $20^{\circ} \mathrm{C}, 30{ }^{\circ} \mathrm{C}$, and $40{ }^{\circ} \mathrm{C}$, respectively, when the heat pump system worked and discharged heat energy to the storage tank. All of these simulation results showed that the quality of the waste water temperature improved approximately $150 \%, 70 \%$ and $40 \%$ at the waste water temperatures of $20{ }^{\circ} \mathrm{C}, 30{ }^{\circ} \mathrm{C}$, and $40{ }^{\circ} \mathrm{C}$, respectively. The maximum heating coefficient of performance was found as 3.77 for the highest flow rate of the circulation pump and 40 
${ }^{\circ} \mathrm{C}$ of waste water temperature value. On the other hand, the minimum $\mathrm{COP}_{\text {heat }}$ value was determined as 1.77 for the highest cycle value of the circulation pump and $40{ }^{\circ} \mathrm{C}$ of waste water temperature. The uncertainty value was determined in the range of $\pm(1.92 \%-4.18 \%)$. The mean $\mathrm{COP}_{\text {heat }}$ increases as the waste water temperatures increases according to the Eqn. 3. The increase in the temperatures of wastewater was not observed to be increasing the heating coefficient of performance in considerable amounts during the conducted experiments. The mean $\mathrm{COP}_{\text {heat }}$ of the all conditions was found as approximately 2.6, as can be seen in Table 3. This finding is compatible with the results of the many studies in the literature. This value can be interpreted as using heat pumps instead of electrical heating devices for hot water production, which can reduce the heating energy cost of the building or hot water production

about $160 \%$. Alternatively, the re-using of the waste water fluids can be considered for example; high temperature waste water heat sources such as more than $40{ }^{\circ} \mathrm{C}$ can be firstly passed from a heat exchanger and then the water temperature can be decreased to as low as $20{ }^{\circ} \mathrm{C}$. Later, this waste water can be reused as a heat source in the heat pump system and thus the system can provide more benefits and higher heating coefficient of performance.

It has also been observed in the experiments that the compressor experiences operational difficulties due to excessive pressure increase of compressor outlet and the heating coefficient of performance decreases by extreme amounts when the temperature in the energy storage tank is increased to as high as $50^{\circ} \mathrm{C}$. It can be recommended that a supportive separate electric heater system in the usage hot water line might be inserted for the heat pump systems to produce utilization water higher temperature than $50^{\circ} \mathrm{C}$. It was also observed that the efficiency of the heat pump was decreased as the utilization water temperature in the storage tank increased during all experiments carried out in this experimental study. Therefore, the heat transfer rate from the waste water to the water in a large storage tank in terms of heat pump or using low temperature water from the urban water supply for the pre-heating process would enable the system work with higher performance. It would be preferable to utilize a forced air circulated fan coils type heating devices or floor heating systems instead of natural convection heat transfer exchanger when the hot water produced from the present system is used for heating purposes. The results of this application also show that the proposed system can be satisfactorily adopted anywhere in the World. The main disadvantage of these systems is their higher initial cost compared to other water heating systems. Considering the rapid growth of energy consumption of the developing countries and energy imports in recent years, usage of heat pump systems for heating, cooling and usage of waste water sources in these systems might be supported by the governments.

\section{Notation:}

$\begin{array}{lll}\mathrm{c}_{\mathrm{p}} & \mathrm{J} / \mathrm{kg}^{\circ} \mathrm{C} & \text { specific heat of water } \\ m_{w w} & \mathrm{~kg} / \mathrm{s} & \text { mass flow rate of waste water } \\ m_{h w} & \mathrm{~kg} / \mathrm{s} & \text { mass flow rate of hot water } \\ \mathrm{P}_{\mathrm{c}} & \mathrm{bar} & \text { compressed line pressure of the compressor } \\ \mathrm{P}_{\mathrm{S}} & \mathrm{bar} & \text { suction line pressure of the compressor } \\ \mathrm{t} & \text { min. } & \text { time }\end{array}$




\begin{tabular}{|c|c|c|}
\hline $\mathrm{Q}_{\mathrm{e}}$ & W & evaporative cooling capacity \\
\hline $\mathrm{Q}_{\mathrm{c}}$ & $\mathrm{W}$ & condenser heating capacity \\
\hline $\mathrm{T}_{\mathrm{a}}$ & ${ }^{\circ} \mathrm{C}$ & waste water temperature \\
\hline $\mathrm{T}_{\mathrm{ww}, \mathrm{ei}}$ & ${ }^{\circ} \mathrm{C}$ & temperature of the waste water at the evaporator inlet \\
\hline $\mathrm{T}_{\mathrm{ww}, \mathrm{ee}}$ & ${ }^{\circ} \mathrm{C}$ & temperature of the waste water at the evaporator exit \\
\hline $\mathrm{T}_{\text {hw,ci }}$ & ${ }^{\circ} \mathrm{C}$ & $\begin{array}{l}\text { temperature of the hot water (i.e., transport water) at the } \\
\text { condenser inlet }\end{array}$ \\
\hline $\mathrm{T}_{\mathrm{hw}, \mathrm{ce}}$ & ${ }^{\circ} \mathrm{C}$ & $\begin{array}{l}\text { temperature of the hot water (i.e., transport water) at the } \\
\text { condenser exit }\end{array}$ \\
\hline$\Delta \mathrm{T}_{\mathrm{c}}$ & ${ }^{\circ} \mathrm{C}$ & hot water temperature difference at the condenser inlet and exit \\
\hline $\mathrm{W}_{\text {comp }}$ & $\mathrm{W}$ & power consumption of the compressor \\
\hline $\mathrm{W}_{\text {pumps }}$ & $\mathrm{W}$ & power of the circulation pumps \\
\hline $\mathrm{W}_{\text {tot }}$ & $\mathrm{W}$ & total power consumption of the system \\
\hline $\mathrm{COP}_{\text {heat }}$ & & Heating Coefficient of Performance \\
\hline $\begin{array}{l}\mathrm{COP}_{\text {heat,ave }} \\
V_{h w}\end{array}$ & $\mathrm{~m}^{3} / \mathrm{s}$ & $\begin{array}{l}\text { Time averaged mean of Heating Coefficient of Performance } \\
\text { volumetric flow rate of hot water }\end{array}$ \\
\hline$\rho_{h w}$ & $\mathrm{~kg} / \mathrm{m}^{3}$ & density of hot water \\
\hline$W_{x i}$ & & the accuracy or error of the measured parameter \\
\hline
\end{tabular}

\section{Acknowledgements}

This work was supported by the Research Fund of Selcuk University (BAP No: 06101005).

\section{References}

1. Büyükalaca, O.; Ekinci, F.; Y1lmaz, T. Experimental investigation of Seyhan River and dam lake as heat source-sink for a heat pump. Energy 2003, 28, 157-169.

2. Kokkinides, L.; Sachs, H.M. Toward market transformation: commercial heat pump water heaters for the "New York Energy Smarts Region". Prepared for The New York State Energy Research and Development Authority; American Council for an Energy-Efficient Economy: New York, NY, USA, October 2002.

3. Kim, M.; Kim, M.S.; Chung, J.D. Transient thermal behavior of a water heater system driven by a heat pump. Int. J. Refrig. 2004, 27, 415-421.

4. Mason, R.S.; Bierenbaum, H.S. Energy conservation through heat recovery water heating. ASHRAE J. 1977, 19, 36-40.

5. Zhang, J.; Wang, R.Z.; Wu, J.Y. System optimization and experimental research on air source heat pump water heater. Appl. Therm. Eng. 2007, 27, 29-35.

6. Luo, Q.; Tang, G.; Liu, Z.; Wang, J. A novel water heater integrating thermoelectric heat pump with separating thermosiphon. Appl. Therm. Eng. 2005, 25, 2193-2203.

7. Neksa, P.; Rekstad, H.; Zakeri, G.R.; Schiefloe, P.A. $\mathrm{CO}_{2}$-heat pump water heater: characteristics, system design and experimental results. Int. J. Refrig. 1998, 21, 172-179. 
8. Hepbasli, A.; Kalinci, Y. A review of heat pump water heating systems. Renew. Sust. Energ. Rev. 2009, 13, 1211-1229

9. Doğan, V. Heat recovery and water to water heat pump application. 99' TESKON PROGRAM BILLDIRILERİ: Ankara, Turkey, 1999 (in Turkish).

10. Baek, N.C.; Shin, U.C.; Yoon, J.H. A study on the design and analysis of a heat pump heating system using waste water as a heat source. Sol. Energy 2005, 78, 427-440.

11. Phetteplace, P.E. Primary effluent as heat source for heat pumps. ASHRAE Trans. 1989, 95, 141-146.

12. Berntsson, T. Heat sources-technology, economy and environment. Int. J. Refrig. 2002, 25, 428-438.

13. Kavanaugh, S.P. Design considerations for ground and water source heat pumps in southern climates. ASHRAE Trans. 1989, 95, 1139-1149.

14. Kavanaugh, S.P.; Woodhouse, J.G.; Carter, J.R. Test results of water-to-air heat pumps with high cooling efficiency for ground-coupled applications. ASHRAE Trans. 1991, 97, 895-901.

15. ASHRAE Systems and Equipment Handbook (SI); ASHRAE: Washington, DC, USA, 1992; Chapter 47.

16. Niess, R.C. Applied heat pump opportunities in commercial buildings. ASHRAE Trans. 1989, 95, 493-498.

17. Çelebi, A. Simulation of Heat Pump System with Waste Heat Recovery. M. Sc. Thesis. Selçuk University: Konya, Turkey, 2006 (in Turkish).

18. Cost comparison chart of fuels for housing in Turkey. Nat. Gas Technol. Equip. Syst. Mag. 2009, 145, 1 (in Turkish).

19. Çengel, Y.A.; Boles, M.A. Thermodynamics: An Engineering Approach, 7th ed.; McGraw-Hill Professional: New York, NY, USA, 2006.

20. Kanoglu, M. Uncertainty analysis of cryogenic turbine efficiency. Math. Comput. Appl. 2000, 5, $169-177$.

21. Wheeler, A.J.; Ganji, A.R. Introduction to Engineering Experimentation; Prentice Hall: Upper Saddle River, NJ, USA, 1996.

(C) 2009 by the authors; licensee Molecular Diversity Preservation International, Basel, Switzerland. This article is an open-access article distributed under the terms and conditions of the Creative Commons Attribution license (http://creativecommons.org/licenses/by/3.0/). 